\title{
Development
}

\section{Translatome Regulation in Neuronal Injury and Axon Regrowth}

\author{
Meir Rozenbaum, ${ }^{1,}$ ( Marek Rajman,, ${ }^{1,}$ Ida Rishal, ${ }^{1}$ Indrek Koppel, ${ }^{1}$ Sandip Koley, ${ }^{1}$ Katalin F. \\ Medzihradszky, ${ }^{2}$ Juan A. Oses-Prieto, ${ }^{2}$ Riki Kawaguchi, ${ }^{3}$ Paul S. Amieux, ${ }^{4}$ Alma L. Burlingame, ${ }^{2}$ \\ (1) Giovanni Coppola, ${ }^{3}$ and ${ }^{-}$Mike Fainzilber ${ }^{1}$
}

\section{DOI:http://dx.doi.org/10.1523/ENEURO.0276-17.2018}

${ }^{1}$ Department of Biomolecular Sciences, Weizmann Institute of Science, Rehovot 76100, Israel, ${ }^{2}$ Department of Pharmaceutical Chemistry, University of California San Francisco, San Francisco, CA 94158-2517, ${ }^{3}$ Departments of Psychiatry and Neurology, Semel Institute for Neuroscience and Human Behavior, University of California Los Angeles, Los Angeles, CA 90095, and ${ }^{4}$ Department of Pharmacology, University of Washington, Seattle, WA 98195

\begin{abstract}
Transcriptional events leading to outgrowth of neuronal axons have been intensively studied, but the role of translational regulation in this process is not well understood. Here, we use translatome analyses by ribosome pull-down and protein synthesis characterization by metabolic isotopic labeling to study nerve injury and axon outgrowth proteomes in rodent dorsal root ganglia (DRGs) and sensory neurons. We identify over 1600 gene products that are primarily translationally regulated in DRG neurons after nerve injury, many of which contain a 5'UTR cytosine-enriched regulator of translation (CERT) motif, implicating the translation initiation factor Eif4e in the injury response. We further identified approximately 200 proteins that undergo robust de novo synthesis in the initial stages of axon growth. ApoE is one of the highly synthesized proteins in neurons, and its receptor binding inhibition or knockout affects axon outgrowth. These findings provide a resource for future analyses of the role of translational regulation in neuronal injury responses and axon extension.
\end{abstract}

Key words: axon growth; axon injury; nerve regeneration; translational regulation

\section{Significance Statement}

Translatome analyses are used to identify a large cohort of genes that are primarily translationally regulated after nerve injury. Many of these contain a 5'UTR cytosine-enriched regulator of translation (CERT) motif, suggesting that the translation initiation factor Eif4e may be involved in the injury response. A number of gene products are robustly synthesized in growing axons. The findings suggest that translational events regulate the neuronal injury response.

\section{Introduction}

Axonal injury to peripheral neurons elicits a sequence of molecular and cellular events that are required for a successful regenerative response (Rishal and Fainzilber, 2014; Terenzio et al., 2017). Information on the lesion is con-

Received August 8, 2017; accepted April 2, 2018; First published April 18, 2018.

The authors declare no competing financial interests.

Author contributions: M.Ro., M.Ra., A.L.B., G.C., and M.F. designed research; M.Ro., M.Ra., I.R., I.K., S.K., K.F.M., J.A.O.-P., and R.K. performed research; P.S.A. contributed unpublished reagents/analytic tools; M.Ro., M.Ra., I.R., I.K., S.K., K.F.M., J.A.O.-P., R.K., A.L.B., G.C., and M.F. analyzed data; M.Ro., M.Ra., and M.F. wrote the paper. veyed to the cell body via retrograde calcium waves or macromolecular transport complexes (Perry et al., 2012; Shin et al., 2012; Cho et al., 2013). These retrograde signals elicit extensive transcriptional responses on arrival at the neuronal cell body (Michaelevski et al., 2010b;

This work was supported by grants from the Dr. Miriam and Sheldon G. Adelson Medical Research Foundation (M.F., G.C., and A.L.B.), the European Research Council (Neurogrowth; M.F.), the Israel Science Foundation (1284/ 13; M.F.), and the Minerva Foundation (M.F.). M.F. is the incumbent of the Chaya Professorial Chair in Molecular Neuroscience at the Weizmann Institute of Science.

${ }^{\star} M$. Ro. and M.Ra. contributed equally to this work. 
Ben-Yaakov et al., 2012), reflected by the large number of regeneration-associated genes that have been described in different paradigms of neuronal injury (Dulin et al., 2015; Chandran et al., 2016; Tasdemir-Yilmaz and Segal, 2016). Transcriptional regulation has been the main focus to date in the analysis of injury-induced changes in gene expression, while the role of translation has been examined mainly in the context of localized responses in the axon (Zheng et al., 2001; Michaelevski et al., 2010a; Jung et al., 2012; Twiss et al., 2016). Does initiation of regeneration require the neuronal cell body to change patterns of translation in addition to or differently from the transcriptional regulation that is known to occur?

An early study showed that cultured sensory neurons can extend new neurites in the absence of ongoing transcription during the first phase of outgrowth in vitro, but require new transcription for longer term elongating growth (Smith and Skene, 1997). Others described a role for ribosomal protein translation in axon growth under transcriptional repression (Twiss et al., 2000), and more recent studies have implicated translational repression and ribosome biogenesis as rate-limiting mechanisms for axon or dendrite growth (Slomnicki et al., 2016; Williams et al., 2016). A number of studies have shown that axon growth requires local protein synthesis (Zheng et al., 2001; Jiménez et al., 2005; Verma et al., 2005) and that changes in the balance between synthesis in axon versus soma affects axonal growth rates (Perry et al., 2016), but the overall contribution of soma translational regulation in axon outgrowth has not been comprehensively characterized to date.

Translating ribosome affinity purification (TRAP) and metabolic labeling are two types of approaches that can provide comprehensive analyses of translatome and proteome dynamics during the injury response. The first uses ribosome pull-downs followed by RNA-sequencing (RNAseq) to identify RNAs associated with ribosomes in the cell or tissue of interest (Brar and Weissman, 2015). Studies of this nature in the nervous system typically take advantage of genetic tagging of ribosomes in the cell types of interest with GFP or HA epitope tags, to allow pull-down of the desired ribosome population directly from tissue lysates (Heiman et al., 2008; Sanz et al., 2009). This type of approach has been used for molecular profiling of diverse aspects of neuronal physiology, including activity (Tao et al., 2016), development (Shigeoka et al., 2016), maturation (Zhang et al., 2016), and pathology (Sun et al., 2015). However, ribosomal association alone may not necessarily reflect translational activation, since mRNAs

Acknowledgments: We thank Dr. Qing Wang for assistance with RNA-seq library preparation and the University of California Los Angeles Neuroscience Genomics Core (www.semel.ucla.edu/ungc) for assistance with RNA-seq data generation.

Correspondence should be addressed to Mike Fainzilber at the above address, E-mail: mike.fainzilber@weizmann.ac.il.

DOI:http://dx.doi.org/10.1523/ENEURO.0276-17.2018

Copyright (C) 2018 Rozenbaum et al.

This is an open-access article distributed under the terms of the Creative Commons Attribution 4.0 International license, which permits unrestricted use, distribution and reproduction in any medium provided that the original work is properly attributed. may remain associated with ribosomes under translational arrest (Ingolia et al., 2011), and non-coding RNAs are also a prominent component of ribosome pull-downs (Carlevaro-Fita et al., 2016). Hence, metabolic labeling for direct monitoring of protein synthesis can provide a valuable complementary approach.

Metabolic labeling coupled with mass spectrometry analysis provides direct assessment of translational activity on a proteome-wide scale. In the stable isotopic labeling of amino acids in culture (SILAC) approach, differential proteome labeling is achieved by culturing cells in media containing different isotopes of an essential amino acid (Ong et al., 2002). SILAC was originally developed for dividing cells, and uniform labeling may require three to five cell divisions in culture. Although $70 \%-80 \%$ label incorporation has been reported in rapidly growing embryonic neurons after $3 \mathrm{~d}$ of culture (Spellman et al., 2008), non-dividing cells such as neurons are more easily assessed by pulsed or multiplex labeling approaches (Hoedt et al., 2014; Zhang et al., 2014). These and other variants of SILAC have been employed to characterize diverse aspects of neuronal cell physiology, such as synaptic protein turnover (Cohen et al., 2013), synapse development (Ultanir et al., 2014), and signaling endosome dynamics (Debaisieux et al., 2016). Here, we employ TRAP, RNA-seq, and SILAC-based methods to interrogate the translational response to nerve injury in dorsal root ganglia (DRGs) and in sensory neurons.

\section{Materials and Methods}

\section{Animals, injury models, and neuronal cultures}

The study was conducted in accordance with the guidelines of the Institutional Animal Care and Use Committee. Male mice at 8-12 weeks of age were used for ribosome pull-down and RNA-seq experiments. The following mouse strains were used: RiboTag (Sanz et al., 2009), Adv Cre (Zhou et al., 2010; da Silva et al., 2011), Is/1 Cre (Yang et al., 2006), Dhh Cre (Jaegle et al., 2003), Runx3 Cre (Levanon et al., 2011), PGK Cre (Lallemand et al., 1998), and $A p o E$ null (Piedrahita et al., 1992). Wistar rats were used for proteomics analyses and C57BL/6 YFP16 mice (Feng et al., 2000) for functional validation of selected candidates. Cultures of control and conditionally injured primary sensory neurons from mouse or rat DRG were performed as described previously (Hanz et al., 2003; Perry et al., 2012). For proteomics, adult Wistar rats were subjected to sciatic nerve (SN) crush, and L4-6 DRG were isolated for culturing $3 \mathrm{~d}$ later. Control and injuryconditioned ganglia were dissociated with $500-\mathrm{U} / \mathrm{ml}$ collagenase (Sigma) and grown in Neurobasal A medium with B27 supplement (Invitrogen) containing L-Lysine: $2 \mathrm{HCl}$ (13C6, 99\%; 15N2, 99\%, Cambridge Isotope Laboratories) for 24,30 , and $48 \mathrm{~h}$.

Discrimination between axons and cell bodies of neuronal cultures was achieved by culturing the cells in modified Boyden chambers (Willis and Twiss, 2011). In this system, neurons are plated on filter inserts containing a polyethylene tetraphthalate membrane with $3-\mu \mathrm{m}$ pores (Millipore) that had been coated with poly-L-lysine (Sigma) and laminin (Invitrogen). Neurons from 15-20 DRGs were 
plated per insert, and axon-enriched protein extracts were prepared (Zheng et al., 2001; Willis and Twiss, 2011). Briefly, cell bodies and non-neuronal cells were removed from the upper membrane surface, followed by extraction of the axon-enriched lower side of the membrane using a modified RIPA buffer [50 mM Tris- $\mathrm{HCl}(\mathrm{pH} 7.4), 150 \mathrm{mM}$ $\mathrm{NaCl}, 0.5 \% \mathrm{NP}-40$, and $0.1 \% \mathrm{SDS}$ ] with protease inhibitors (Roche). Multiple biological replicates corresponding to five to seven animals each were combined and concentrated using centrifugal filters (Amicon Ultra, $3 \mathrm{kDa}$; Millipore). Protein concentration was measured with the Micro BCA Protein Assay (Thermo Scientific). Equal protein amounts were separated by 1D SDS-PAGE (10\%) and stained with Novex Colloidal Blue (Invitrogen). Each gel lane was cut into 15 parts. Gel pieces were reduced, alkylated and digested with trypsin (https://msf.ucsf.edu/ protocols.html), followed by on-line high-pressure liquid chromatography/mass spectrometry (LC/MS) using a NanoACQUITY-LTQ-Orbitrap XL system (Waters and Thermo Scientific, respectively). Each digest mixture was analyzed over 90-min fractionation on a C18 reversedphase nanocolumn. Masses were measured in the Orbitrap, collision-induced dissociation on the six most abundant multiply charged ions of the MS survey was performed in the linear trap, and fragment masses were also detected there.

Transcription inhibition experiments on neuronal cultures were conducted by culturing adult rat DRG neurons with or without the RNA polymerase II inhibitor 5,6-dichloro-1- $\beta$-Dribofuranosylbenzimidazole riboside (DRB; Sigma) at $80 \mu \mathrm{M}$ final concentration. After $12 \mathrm{~h}$, the DRB-containing medium was removed and cultures were washed twice with warm PBS. Fresh growth medium (DMEM/F12 + 10\% $\mathrm{HS}+\mathrm{N} 2+\mathrm{P} / \mathrm{S}$ ) was then added and cultures were continued for up to 24,36 , and $48 \mathrm{~h}$. Axons extending to the lower surface of the insert were identified by immunostaining for $\beta 3$-tubulin (MAB1195; R\&D Systems). Neurite outgrowth was analyzed using Neuromath (Rishal et al., 2013).

\section{Antibodies and immunostaining}

Primary antibodies used for Western blottings were as follows: rat anti-HA (Roche catalog 11-867-423), mouse anti-RPS5 (Abcam, ab58345), rabbit anti-RPS18 (Abcam, ab91293), rabbit anti-RPS15 (Abcam, ab90902), rabbit anti-RPL11 (Abcam, ab79352), rabbit anti-TUJ1 (Covance catalog $\mathrm{MRB}_{435} \mathrm{P}$ ), mouse anti-Rpl22 (Santa Cruz Biotechnology, sc-373993), rabbit anti-gERK (Sigma, M5670), and rabbit anti-albumin (Cedarlane, CLAG5140).

Primary antibodies used for immunostaining were as follows: rat anti-HA (Roche catalog 11-867-423), mouse Y10B (Abcam catalog ab37144), rabbit anti-TUJ1 (Covance catalog $\mathrm{MRB}_{435} \mathrm{P}$ ), rat anti-MBP (Millipore, MAB395$1 \mathrm{ML}$ ), and chicken anti-NFH (Abcam, ab72996). Fluorescent secondary antibodies were from Jackson ImmunoResearch. Staining was observed using an Olympus FV1000 Confocal laser-scanning microscope at $40 \times$ or $60 \times$ magnification with oil-immersion Olympus UPLSAPO objective and was analyzed with FV10-ASW2.0 software.

\section{RiboTag analyses and RNA-seq}

Cre driver lines were crossed with RiboTag mice to generate animals heterozygous for Cre and homozygous for the Rp/22-HA allele, except for Advillin-Cre crosses that were used as heterozygotes for both alleles. Tissues were extracted and HA immunoprecipitation (IP) was conducted as previously described (Sanz et al., 2009), with slight modifications. Briefly, DRG or neurons resuspended from culture were homogenized on ice in supplemented homogenization buffer [50 mM Tris $(\mathrm{pH} 7.0), 100 \mathrm{mM} \mathrm{KCl}$, $12 \mathrm{mM} \mathrm{MgCl} 2,1 \% \mathrm{NP}-40$, and $1 \mathrm{mM}$ DTT, $1.5 \times$ protease inhibitor cocktail, 300 units $/ \mathrm{ml}$ RNasin (Promega), 150$\mu \mathrm{g} / \mu$ l cyclohexamide, and $200 \mathrm{mM}$ RVC] using 2-ml glass Teflon Potter Elv tissue grinders. After homogenization, lysates were transferred to Eppendorf tubes and centrifuged at $4^{\circ} \mathrm{C}$ for $10 \mathrm{~min}$ at $6,932 \times \mathrm{g}$. Supernatants were collected to low bind tubes and $10 \%$ of each sample was set aside as input; $5 \mu \mathrm{g}$ of anti-HA antibody was added to each sample and incubated on rotator for $4 \mathrm{~h}$ at $4^{\circ} \mathrm{C}$. Magnetics beads were washed with the homogenization buffer and added to the Ab-homogenates mix, $100 \mu \mathrm{l}$ of beads per sample, for overnight incubation at $4^{\circ} \mathrm{C}$ on rotor. Beads were washed three times, 5 min each, with high salt buffer [50 mM Tris (pH 7.0), $300 \mathrm{mM} \mathrm{KCl,} 12 \mathrm{mM}$ $\mathrm{MgCl}_{2}, 1 \% \mathrm{NP}-40$, and $1 \mathrm{mM} \mathrm{DTT}, 1 \times$ protease inhibitor cocktail, 200 units/ml RNasin, and $150-\mu \mathrm{g} / \mu \mathrm{l}$ cycloheximide]. After washes, RNA was eluted and purified using the Qiagen RNeasy micro kit including on-column DNase digestion.

RNA-seq libraries were prepared in three to five replicates per condition, using at least $5 \mathrm{ng}$ of starting total RNA for each replicate. Processing was with Ribo-Zero Gold (Epicentre), using the Ovation RNA-seq system V2 (NuGEN). After library preparation, amplified double-stranded cDNA was fragmented into $125 \mathrm{bp}$ (Covaris-S2) DNA fragments, which were $(200 \mathrm{ng})$ end-repaired to generate blunt ends with 5'-phosphates and 3'-hydroxyls and adapters ligated. The purified cDNA library products were evaluated using the Agilent Bioanalyzer and diluted to $10 \mathrm{nM}$ for cluster generation in situ on the HiSeq paired-end flow cell using the CBot automated cluster generation system. All samples were multiplexed into a single pool to avoid batch effects (Auer and Doerge, 2010) and sequenced using an Illumina HiSeq 2500 Sequencer (Illumina) across multiple lanes of 50-bp paired-end sequencing, corresponding to three samples per lane and yielding between 44 and 85 million reads per sample. Quality control was performed on base qualities and nucleotide composition of sequences, with removal of outliers. Alignment to the Mus musculus (mm10) refSeq (refFlat) reference gene annotation was performed using the STAR spliced read aligner (Dobin et al., 2013) with default parameters. On average, $83.7 \pm 8 \%$ of the reads mapped uniquely to the mouse genome. Total counts of read-fragments aligned to candidate gene regions were derived using the HTSeq program (http://htseq.readthedocs.io/) with mouse mm10 (December 2011) refSeq (refFlat table) as a reference and used as a basis for the quantification of gene expression. Only uniquely mapped reads were used for subsequent analyses. Differential expression analysis was con- 
A

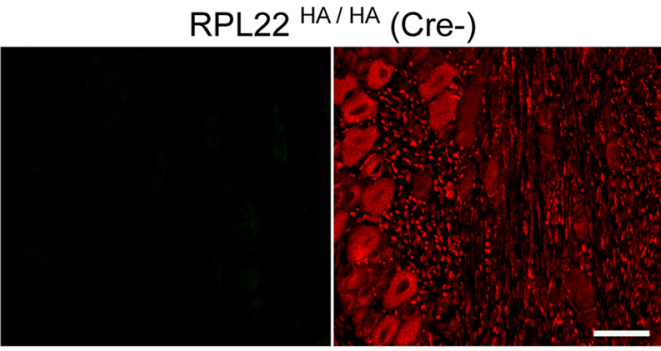

Isl1 Cre X RPL22 HA/ HA

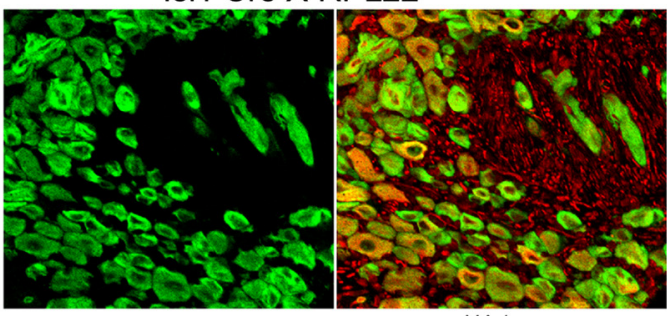

Advillin Cre X RPL22 HA/ +

HA

TUJ1

\begin{tabular}{|l|l|}
\hline Cre line & Cell type expression in DRG \\
\hline Isl1 Cre & Sensory neurons \\
\hline Advillin Cre & Sensory neurons \\
\hline Runx3 Cre & Proprioceptive neurons \\
\hline Dhh Cre & Satellite Glial Cells \\
\hline
\end{tabular}
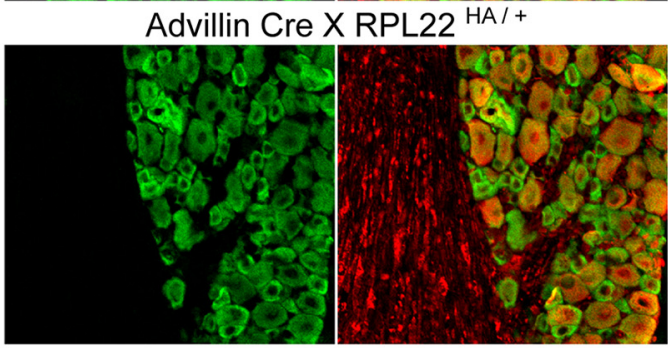

Dhh Cre X RPL22 HA/ HA

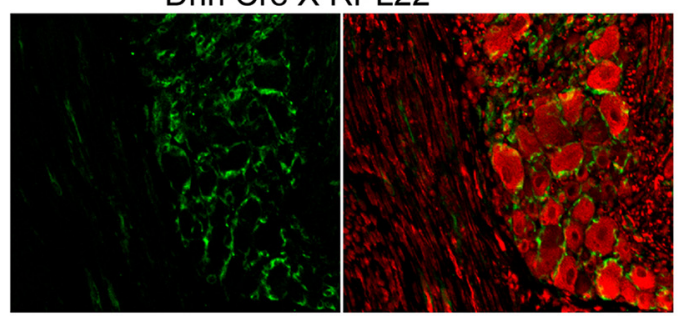

Runx3 Cre X RPL22 HA/HA

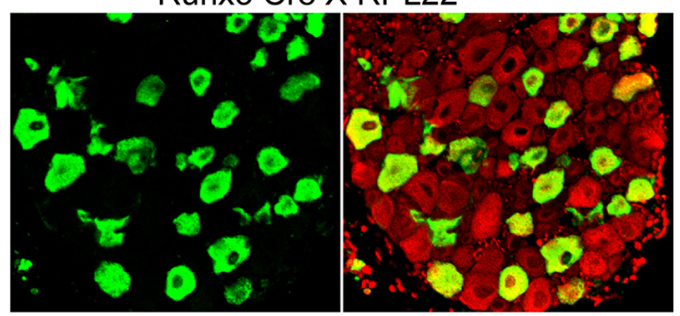

B

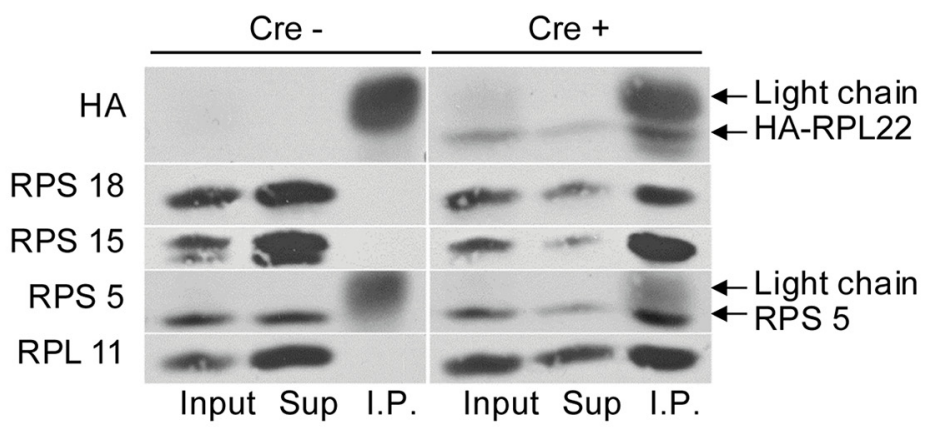

C
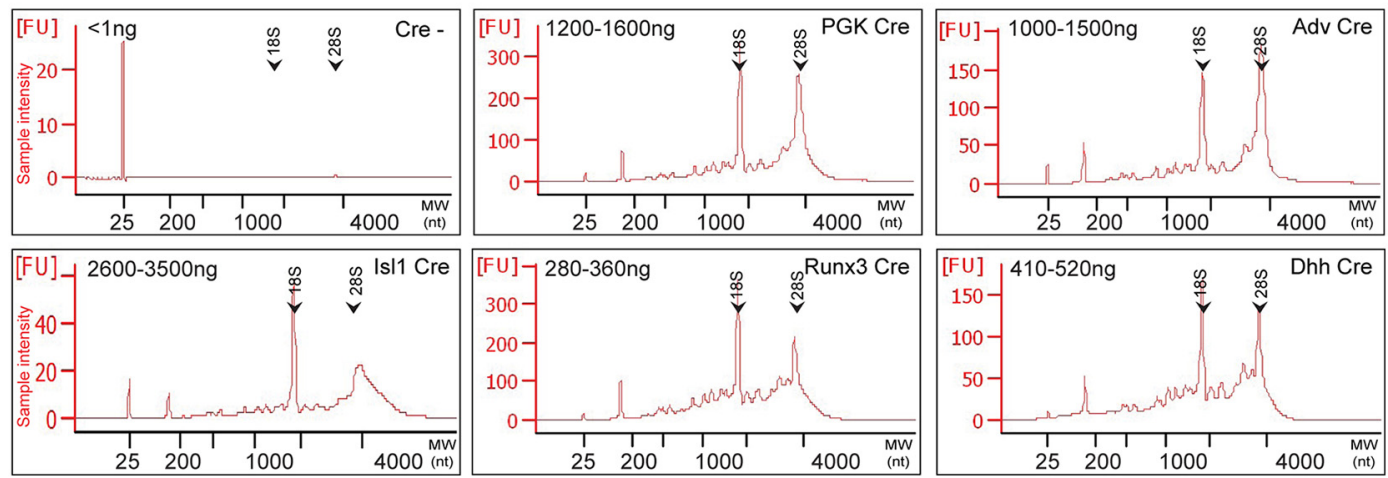

Figure 1. Cell type-specific ribosome isolation from DRG. $\boldsymbol{A}$, DRG sections from adult RiboTag mice with the indicated genotypes immunostained for HA (green, left) and the neuronal marker TUJ1 (red, right). Scale bar: $50 \mu \mathrm{m}$. $\boldsymbol{B}$, Isolation of sensory neuron ribosomal proteins from mouse DRG tissue. Total DRG isolated from four Rpl22 ${ }^{H A / H A}$ (Cre-) and four Advillin-Cre X Rpl22 $2^{H /+}(\mathrm{Cre}+)$ mice were extracted and IP with an HA antibody. Input, supernatant and IP fractions were then probed by Western blotting as indicated. Light chain indicates the precipitating HA antibody light chain. C, Ribosomal RNA coprecipitation with Rpl22-HA from the indicated Cre RiboTag lines. Yields indicated in the upper left corner of each plot are from total DRG homogenate of one mouse (range for three repeats). The arrows indicate migration positions of $18 \mathrm{~S}$ and $28 \mathrm{~S}$ ribosomal RNA peaks. FU, fluorescence units. 
A

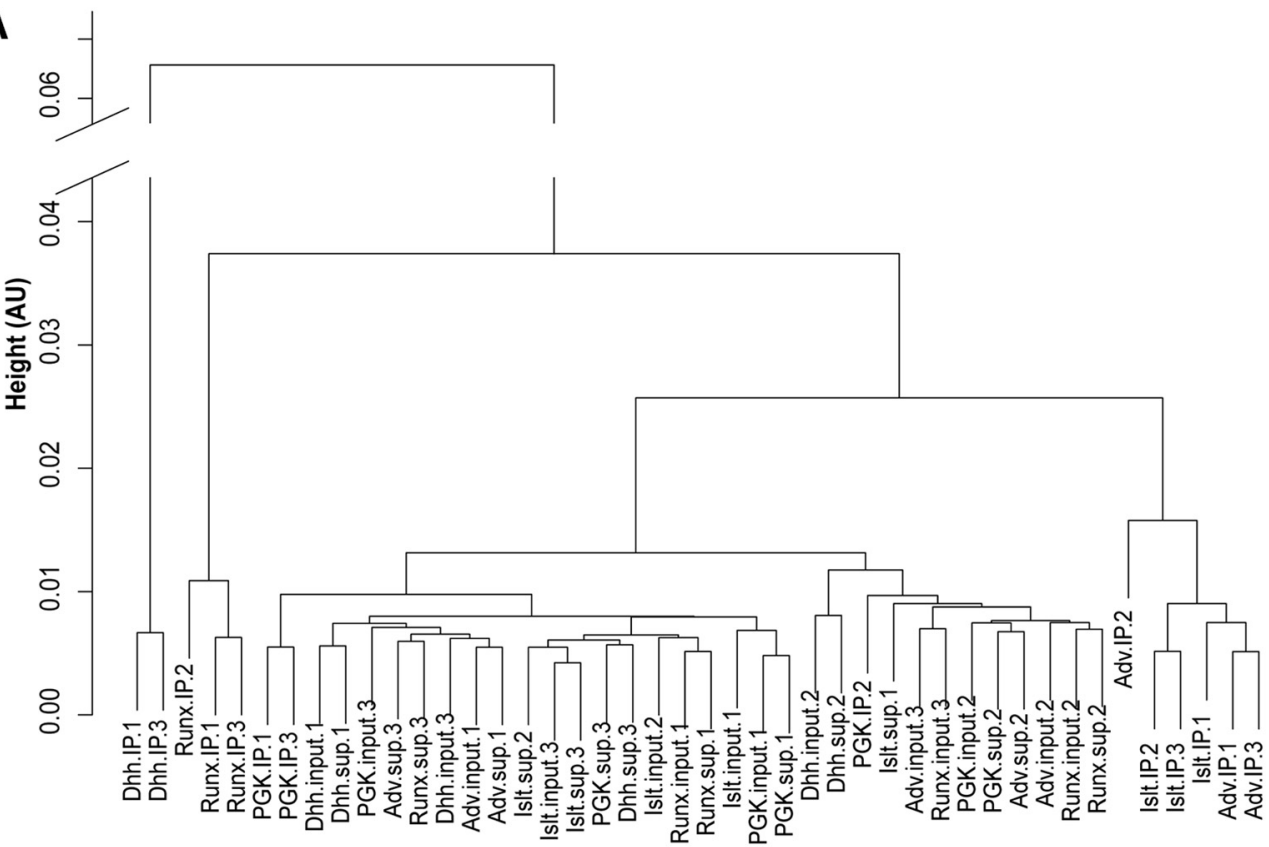

B

Input

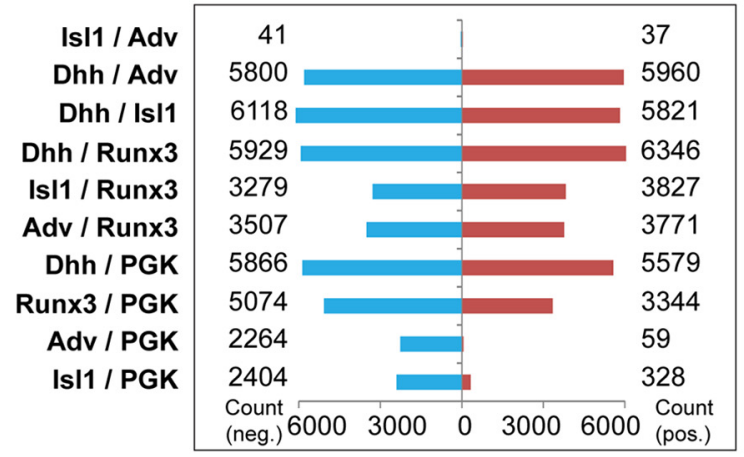

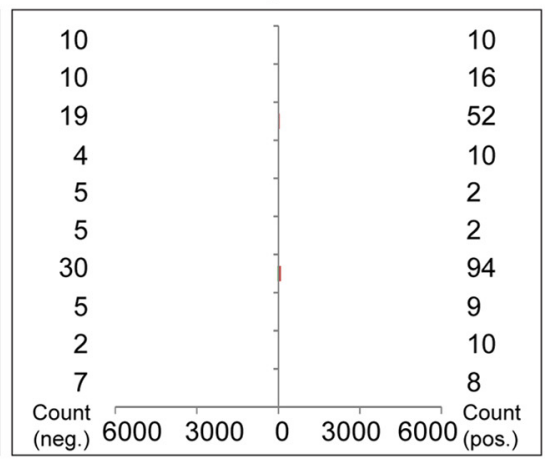

C

GO catagories enrichment analysis Adv Dhh

\begin{tabular}{|l|c|c|}
\cline { 2 - 3 } \multicolumn{1}{c|}{} & P-value & P-value \\
\hline neuronal cell body & $3.0 \mathrm{E}-18$ & $1.0 \mathrm{E}+00$ \\
\hline axon & $2.2 \mathrm{E}-18$ & $1.0 \mathrm{E}+00$ \\
\hline synapse & $1.3 \mathrm{E}-18$ & $8.5 \mathrm{E}-01$ \\
\hline dendrite & $3.5 \mathrm{E}-05$ & $9.7 \mathrm{E}-01$ \\
\hline Growth cone & $1.0 \mathrm{E}-02$ & $8.0 \mathrm{E}-01$ \\
\hline Neuron spine & $1.3 \mathrm{E}-05$ & $9.0 \mathrm{E}-01$ \\
\hline voltage-gated sodium channel complex & $1.5 \mathrm{E}-04$ & - \\
\hline voltage-gated potassium channel complex & $2.3 \mathrm{E}-04$ & $1.0 \mathrm{E}+00$ \\
\hline calcium channel complex & $3.1 \mathrm{E}-04$ & $9.7 \mathrm{E}-01$ \\
\hline chloride channel complex & $8.6 \mathrm{E}-02$ & $9.8 \mathrm{E}-01$ \\
\hline acetylcholine-gated channel complex & $8.8 \mathrm{E}-03$ & $1.0 \mathrm{E}+00$ \\
\hline ionotropic glutamate receptor complex & $1.4 \mathrm{E}-02$ & $4.4 \mathrm{E}+01$ \\
\hline synaptobrevin 2-SNAP-25-syntaxin-1a complex & $7.1 \mathrm{E}-03$ & - \\
\hline neurofilament & $3.4 \mathrm{E}-02$ & $8.8 \mathrm{E}-01$ \\
\hline myelin sheath & $9.4 \mathrm{E}-01$ & $4.2 \mathrm{E}-03$ \\
\hline fibrillar collagen & - & $8.9 \mathrm{E}-05$ \\
\hline sheet-forming collagen & - & $8.5 \mathrm{E}-03$ \\
\hline FACIT collagen & - & $2.2 \mathrm{E}-02$ \\
\hline fibril & - & $2.8 \mathrm{E}-05$ \\
\hline interstitial matrix & - & $6.7 \mathrm{E}-03$ \\
\hline basement membrane & $1.0 \mathrm{E}+00$ & $1.6 \mathrm{E}-12$ \\
\hline
\end{tabular}

D

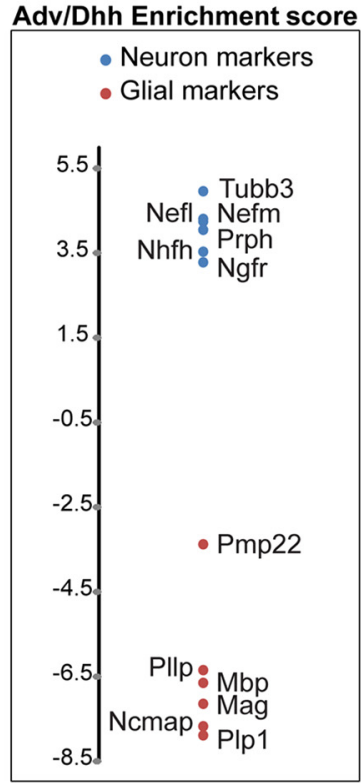

Figure 2. DRG cell type-specific pull-down of ribosome-associated RNAs. A, Hierarchical clustering analysis shows that the mouse 
continued

RiboTag IP samples cluster according to driver Cre identity, whereas input and supernatant samples do not. AU, arbitrary units. $\boldsymbol{B}$, Differential expression analysis of RNA-seq datasets from HA IPs from different Cre RiboTag lines. The differences between the input samples (right) are negligible, whereas marked differences are found for the IP datasets (left), except for the Isl1/Adv comparison. Red bars: upregulated transcripts; blue bars: downregulated transcripts. $\boldsymbol{C}$, GO enrichment analysis on IP datasets reveals clear distinctions between Adv versus Dhh-Cre RiboTag mice; $p$ values for GO category enrichment are shown for each genotype. Blue shading indicates $p<0.05$, red $p>0.05$. $\boldsymbol{D}$, Enrichment analysis for specific neuronal (blue) versus glial (red) markers in Adv versus Dhh RiboTag datasets.

ducted with R-project and the Bioconductor package edgeR (Robinson et al., 2010). Statistical significance of the differential expression was determined at false discovery rate $($ FDR) $<0.1$ (Table 1$)$.

RNA-seq data were deposited within the Gene Expression Omnibus (GEO) repository (www.ncbi.nlm.nih.gov/ geo), accession numbers GSE102316 (RiboTag data from DRG ganglia) and GSE110374 (RiboTag data from neuronal cultures). The Matlab function "clustergram" was used for generating hierarchical trees of differentially expressed genes (DEGs) and generating heatmaps. The "cosine" option was used for distance measurement ("Pdist value") using average linkage ("LinkageValue"). No standardization was used. Gene ontology (GO) term enrichment analyses were done with the Ontologizer GO analysis tool (Bauer et al., 2008; http://ontologizer.de/webstart/), using total genome entries as background and the topologyweighted algorithm to identify-enriched GO terms.

\section{Mass spectrometry analysis}

Peak lists were generated using PAVA_Jul2009. Database search was performed by Protein Prospector v5.4.2 on UniProtKB.2009.12.15.random.concatdatabase, considering rat, mouse and human proteins only (344290/ 21095996 entries searched). Only tryptic peptides were considered, one miscleavage was permitted. Carbamidomethylation of Cys residues was considered as a constant modification in the analysis, while variable modifications included acetyl (protein N-term), acetyl + oxidation (protein N-term M), Gln->pyro-Glu (N-term Q), label: $13 \mathrm{C}(6) 15 \mathrm{~N}(2)(\mathrm{K})$, met-loss (protein N-term M), metloss + acetyl (protein $\mathrm{N}$-term M), and oxidation (M). Two variable modifications per peptide were permitted. Precursor mass tolerance was set at $15 \mathrm{ppm}$, and fragment mass tolerance was $0.8 \mathrm{Da}$. Acceptance criteria: minimal scores were 22 and 15, for proteins and peptides, respec- tively; max E values were 0.05 and 0.1 , for proteins and peptides, respectively. Entry ID redundancy was addressed by translating the UniProt identifiers to UniRef90 (release date 2010-02-09, version 15.14), and a peptide list was generated accordingly. Sequences shared by multiple UniRef90 entries could not be used reliably for quantification, hence were removed from the list. The search engine was also used to calculate light/heavy peptide ratios. Mass survey "scans" were summed up considering a -10 - to +30 -s window around the time the precursor ion was selected for CID analysis. Peak areas representing the first three isotope peaks of the identified peptide and its counterpart serve as the basis for the calculation. The SNR threshold applied was 10, the mass resolution was matched to that set for the Orbitrap data acquisition, i.e., 15,000. Only the best ID was considered in each LC/MS analysis, yielding a single $\mathrm{L} / \mathrm{H}$ value for each light/heavy pair even if both were identified from CID data.

Proteins that featured at least two unique peptides with quantitative information were used for further analysis. Ratios $(H / L)$ were transformed to logarithmic scale with base 2 for calculation of median values. Percentages of incorporation were calculated from the medians.

\section{Results}

\section{Cell type-specific ribosome pull-downs from DRG}

Cell type-specific expression of Rpl22-HA was confirmed by HA immunostaining on DRG sections (Fig. 1A). To verify ribosome pull-down from neuronal tissues, HA pull-downs were analyzed for Rpl22-HA and for coprecipitation of additional ribosomal proteins, Rps18, Rps 15 , Rps5, and Rpl11 (Fig. 1B). Coprecipitating signal for Rpl22 and the four additional ribosomal proteins was detected in RiboTag ganglion pull-downs but not in wild-type con-

Table 1. Statistics

\begin{tabular}{|c|c|c|c|c|}
\hline Data & Data structure & Type of test & Power & Notes \\
\hline Figure 2B & GO enrichment analysis & $\begin{array}{l}\text { Ontologizer } 2 \text { (topology-weighted } \\
\text { algorithm) }\end{array}$ & $p<0.05$ & $\begin{array}{l}\text { Standard settings as described in } \\
\text { Bauer et al. (2008) }\end{array}$ \\
\hline Figure $3 \mathrm{C}$ & Contrast analysis & $\begin{array}{l}\text { EdgeR Genewise Negative Binomial } \\
\text { Generalized Linear Models }\end{array}$ & FDR $<0.1$ & $\begin{array}{l}\text { Genes with FPKM }<1 \text { were } \\
\text { filtered }\end{array}$ \\
\hline Figure 3E & RNA motif occurrence & $\begin{array}{l}\text { MEME (FIMO tool) uses dynamic } \\
\text { programming algorithm to convert } \\
\text { log-odds scores into } p \text { values, } \\
\text { assuming zero-order background } \\
\text { model }\end{array}$ & $p<0.0001$ & $\begin{array}{l}\text { Standard settings as described } \\
\text { in Bailey et al. (2009); } \\
\text { Grant et al. (2011) }\end{array}$ \\
\hline Figure 6C & Normally distributed & ANOVA with Holm-Sidak & $p<0.01$ & \\
\hline Figure 6D & Normally distributed & Student's $t$ test & $p<0.001$ & \\
\hline $\begin{array}{l}\text { Extended Data } \\
\text { Figures } 3-1,7-1\end{array}$ & Differential expression analysis & $\begin{array}{l}\text { EdgeR Genewise Negative Binomial } \\
\text { Generalized Linear Models }\end{array}$ & $\begin{array}{l}\text { Quantile-adjusted conditional } \\
\text { maximum likelihood (qCML) }\end{array}$ & $\begin{array}{l}\text { TMM normalization, genes } \\
\text { with FPKM }<1 \text { were filtered }\end{array}$ \\
\hline
\end{tabular}


A

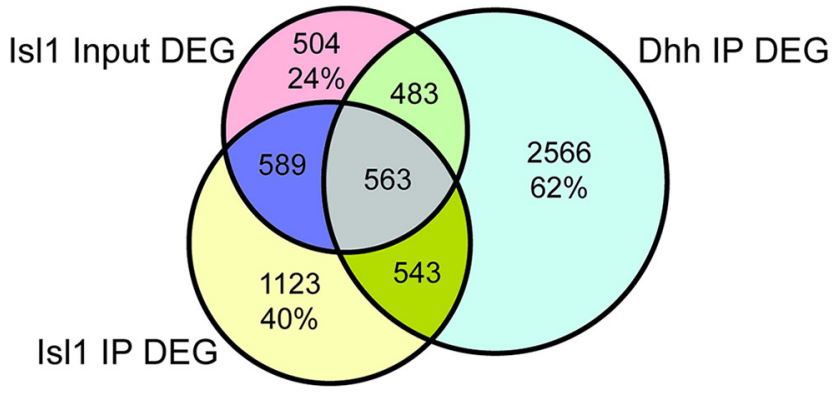

B

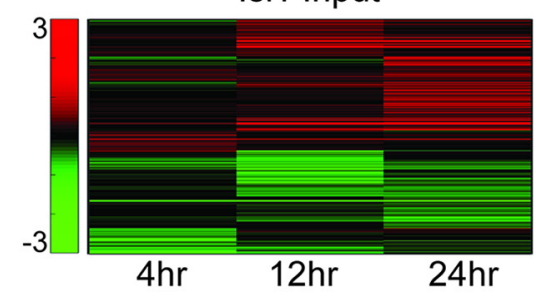

C

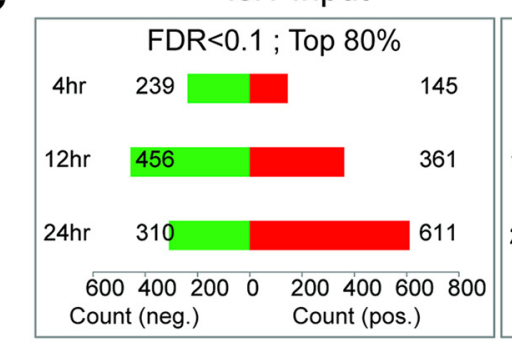

D
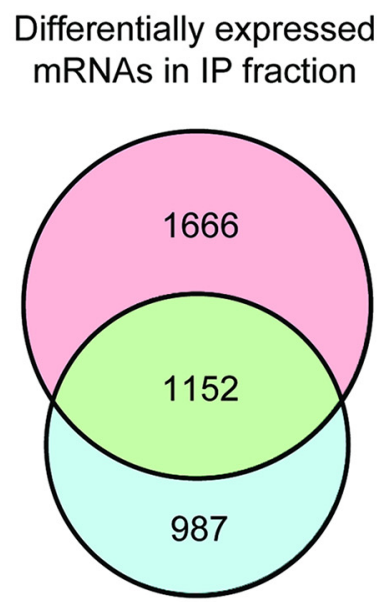

Differentially expressed mRNAs in Input fraction
IsI1 IP

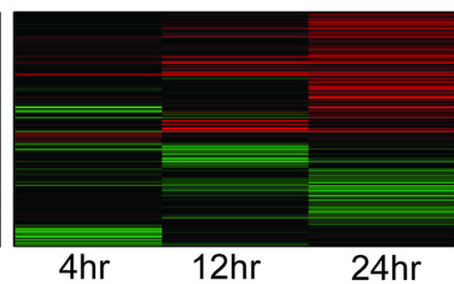

Dhh IP

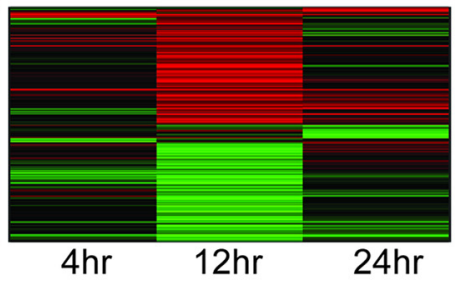

IsI1 IP

Dhh IP

\begin{tabular}{|c|c|c|c|c|c|c|c|}
\hline \multicolumn{3}{|c|}{ FDR< $<0.1$; Top 80\% } & \multicolumn{5}{|c|}{ FDR<0.1; Top 80\% } \\
\hline $4 \mathrm{hr}$ & 305 & 116 & $4 \mathrm{hr}$ & 158 & & & 107 \\
\hline $12 \mathrm{hr}$ & 363 & 370 & $12 \mathrm{hr}$ & 1477 & & & 1440 \\
\hline $24 \mathrm{hr}$ & 498 & 997 & $24 \mathrm{hr}$ & 232 & & & 214 \\
\hline \multicolumn{2}{|c|}{$\begin{array}{rr}1000 & 500 \\
\text { Count (neg.) }\end{array}$} & $\begin{array}{l}10001500 \\
\text { (pos.) }\end{array}$ & $\begin{array}{r}2000 \\
C\end{array}$ & $\begin{array}{c}1000 \\
\text { unt (neg.) }\end{array}$ & 0 & $\begin{array}{c}1000 \\
\text { Count (po }\end{array}$ & $\begin{array}{l}2000 \\
s .)\end{array}$ \\
\hline
\end{tabular}

mRNAs translationally regulated after injury

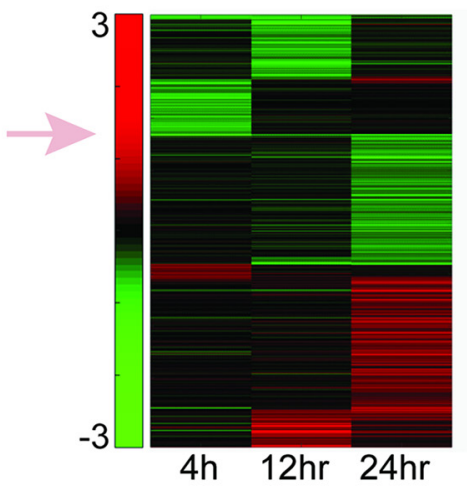

E

Translationally controlled CERT containing mRNAs
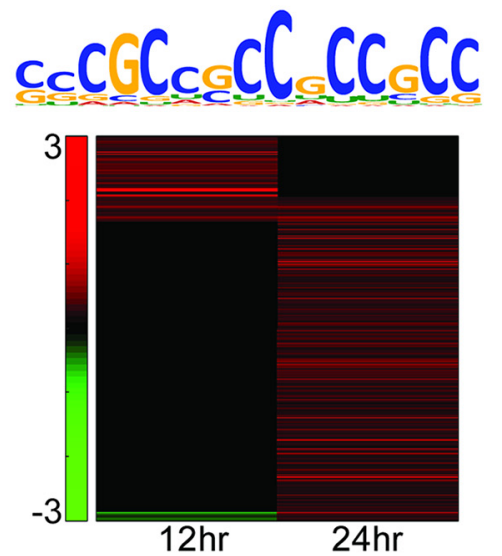

Figure 3. Translatome regulation in the DRG following SN injury. Is/1-RiboTag and Dhh-RiboTag mice underwent a sciatic lesion and L4-5-6 DRG were dissected at 4, 12, or $24 \mathrm{~h}$ after injury. HA-IP reaction was carried on the homogenate followed by RNA-seq analysis on the IP and input samples. Transcripts with FPKM higher than 1 were subjected to a differential expression analysis and compared to the naive samples at each time point. Only transcripts at an FDR lower than 0.1 were considered as differentially expressed. Differential expression in the input samples represents changes in total transcripts' abundance in the DRG tissue. Differential expression in the IP samples represents changes in the association of transcripts with neuronal or glial ribosomes. $\boldsymbol{A}$, Comparison of differentially expressed genes (DEG) between the Input and Isl1 versus Dhh-RiboTag IP fractions. Percentages are the fraction of unique genes from the relevant dataset. $\boldsymbol{B}$, Clustering of the DEG shows different response dynamics over time in the different samples. $\boldsymbol{C}$, The number of down- and upregulated genes in each time point after filtering out the $20 \%$ least changing genes. $\boldsymbol{D}$, DEG 


\section{continued}

lists from the IP and input fraction of the Is/1-Cre RiboTag IP were compared for common and unique entries. In pink are DEG only in the IP fraction that are considered as candidates for translational regulation. In blue are the DEG only in the input fraction. In green are DEG in both the IP and input. The heatmap depicts the translationally regulated genes at each time point. $\boldsymbol{E}$, Revised CERT motif for the neuronal DRG dataset shown above a heatmap depicting log fold change values for CERT-containing transcripts in the dataset. See also Extended Data Figures 3-1, 3-2.

trols, indicating that ribosomes are specifically pulled down only from Rpl22-HA expressing cells. We further examined RNA coprecipitation in RiboTag pull-downs from DRG extracts of all the Cre-RiboTag lines of interest. Both $18 \mathrm{~S}$ and $28 \mathrm{~S}$ ribosomal RNAs were found in all RiboTag pull-downs, compared to undetectable levels in pull-downs from Cre-animals (Fig. 1C). Hence, tagged Rpl22 is specifically expressed in the expected cell types in different Cre driver lines for peripheral ganglia, and Rpl22-HA pull-downs from extracts of whole ganglia can be used to analyze ribosome-associated RNAs in cell types of interest.

\section{Neuronal versus glial translatomes from DRG}

RNA-seq was then conducted on the IP, input and supernatant fractions described in Figure 2. Hierarchical clustering of the sequencing data distinguished IP from input samples, except for PGK-Cre, which is ubiquitously expressed in all tissues. Subclustering of the IP sample datasets followed the predicted cell type specificity of the different Cre drivers (Fig. 2A). Differential expression analysis between IP sample datasets further emphasized the unique composition of ribosome-associated ensembles derived from different Cre lines, except for the Isl1/Adv ensembles which are practically identical (Fig. 2B), due to the expression of these two Cre drivers in all sensory neuron subtypes in the DRG. Parallel comparisons of the input samples showed that they are mostly identical (Fig. $2 B$ ). Cell type specificity of the IPs was further confirmed by GO analysis on Adv-RiboTag (neuronal) versus Dhh-RiboTag (glial) datasets (Fig. 2C), and by comparison of enrichments of specific neuronal versus glial markers in both datasets (Fig. 2D). Thus, RiboTag IPs from DRG extracts enable characterization of RNA ensembles associated with ribosomes in neuronal versus glial cells.

We then proceeded to examine changes in neuronal versus glial translatomes in the DRG following SN injury, using lumbar DRG from Isl1-Cre versus Dhh-Cre RiboTag mice at 4, 12, and $24 \mathrm{~h}$ after injury. Data were filtered such that only transcripts with an fragments per kilobase of transcript per million mapped reads (FPKM) above 1 were considered for further analysis. A differential expression analysis was performed between each time point and naive control with an FDR cutoff of 0.1 . These analyses revealed unique populations of DEGs in input, neuronal RiboTag IP and glial RiboTag IP ensembles (Fig. 3A; Extended Data Figure 3-1). $40 \%$ of the DEG in the neuronal translatome are unique to this ensemble, $62 \%$ of the DEG in the glia are unique, and $24 \%$ of the DEG in the input are not found to be regulated in the RiboTag IP fractions of either neurons or glia. The responses also clearly differ in their kinetics, with marked differences in the time course of DEG regulation in neuronal versus glial translatomes after injury (Fig. 3B,C). Finally, a specific comparison of input versus Isl1-Cre RiboTag fractions highlights over 1600 DEG that change only in the ribosome-bound ensemble, but not in the input (Fig. 3D). This large group of genes is most likely under translational regulation in the first $24 \mathrm{~h}$ after injury, with little or no change in their transcription at the time points examined.

\section{Enrichment of the Eif4e-responsive cytosine-enriched regulator of translation (CERT) motif in the neuronal injury response translatome}

We then applied MEME motif analysis software (Bailey et al., 2009) to search for motifs enriched in the translatome datasets. An initial screen revealed a number of short cytosine-enriched motifs, suggesting that a CERT motif might be overrepresented in the dataset. The CERT motif provides dose-dependent responsiveness to the translation initiation factor Eif4e (Truitt et al., 2015). We retrieved 5'UTR sequences for the previously defined CERTcontaining genes (Truitt et al., 2015), and used these as a training set in MEME, revealing a shared motif highly similar to the published CERT (Fig. 3E). The revised motif is not completely identical to that previously published due to recent updating of a number of the 5'UTR sequences in the refSeq database.

To search for the CERT motif in our data, we retrieved the longest known refSeq 5'UTRs for all translationally regulated genes in four kinetic clusters. We then searched this set for CERT enrichment versus a background set of the 5'UTR sequences of all neuronal transcripts found in RiboTag pull-downs at FPKM $>1$. The CERT motif was found to be enriched in translatome 5'UTRs at 12 and $24 \mathrm{~h}$ after injury and was present in 339 translationally regulated genes (Fig. 3E; Extended Data Figure 3-2). This analysis suggests that Eif4e may be involved in translational regulation of neuronal injury responses via the CERT motif.

\section{Axon outgrowth proteomes reveal robust injury-regulated de novo protein synthesis}

The findings detailed above suggest that translational regulation plays a role in the neuronal response to nerve injury. Conditional injury of SN is used as a model to differentiate between arborizing and elongating regenerative growth of DRG neurons in culture. Conditionally injured neurons initiate axon extension earlier in culture and have longer axons compared to the arborizing neurons at 24-48 $\mathrm{h}$ after plating. To characterize proteome differences between arborizing and elongating growth, we examined incorporation rates of heavy lysine (Lys8) into newly synthesized proteins in axons of compartmentalized rat DRG neuron cultures 24-48 h after plating (Fig. 
A

Sciatic Nerve

L4-6 DRG

Crush

Isolation (Control, Injured)

tor
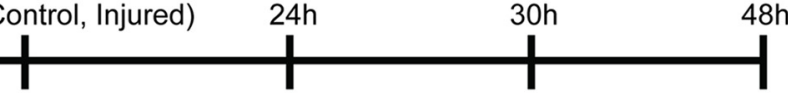

3 days

Cells were grown with "heavy" lysine

B

Control
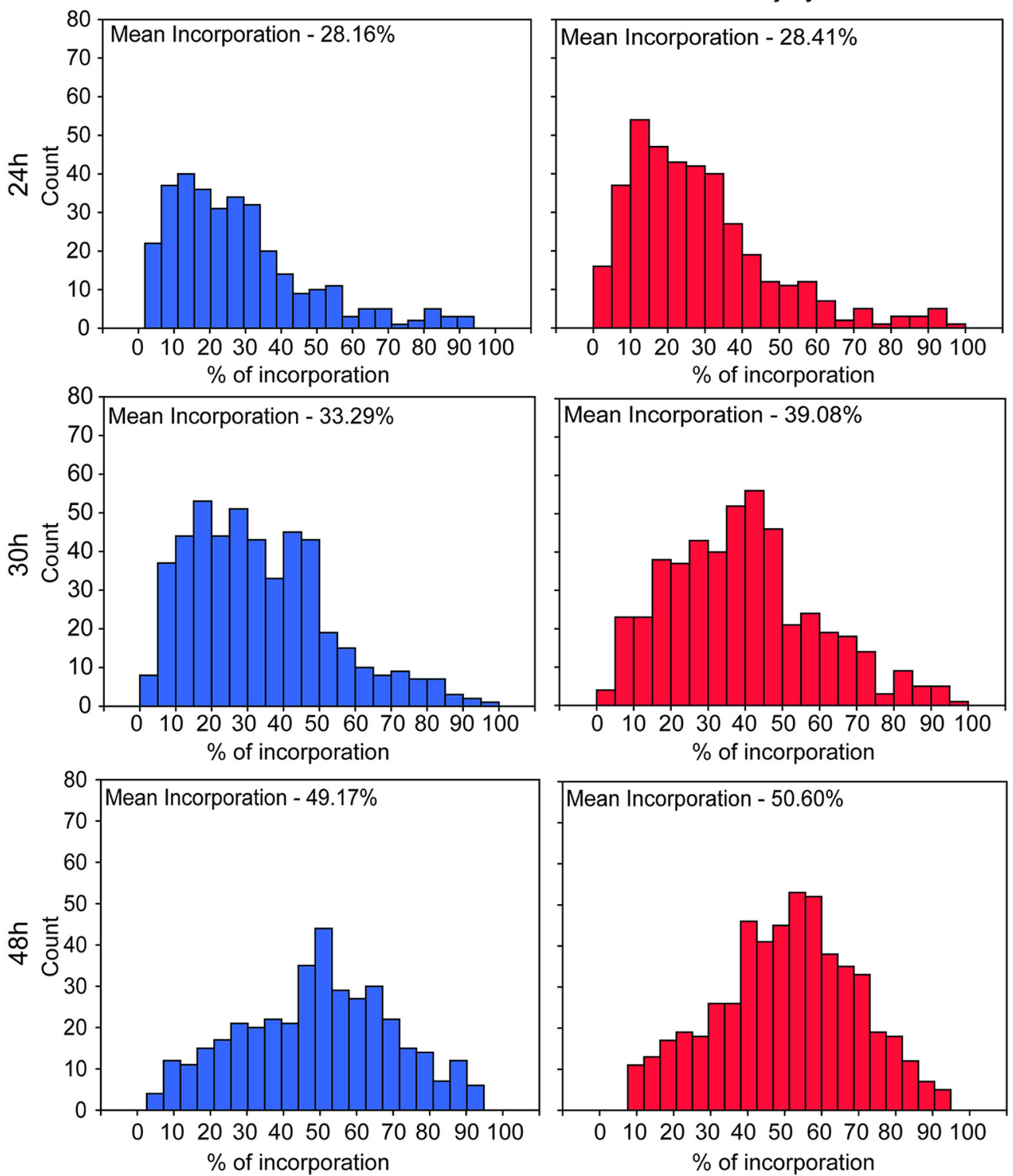

Figure 4. Incorporation of heavy lysine during neurite outgrowth. $\boldsymbol{A}$, Schematic outline of experimental paradigm for SILAC analyses in rat neurons. $\boldsymbol{B}$, Distribution of heavy lysine incorporation in control or conditionally injured neurons 24,30 , and $48 \mathrm{~h}$ after plating (neurite-enriched proteome). There was no difference in protein synthesis rates between control and conditionally-injured neurons.

4A). The average incorporation rate into axonal proteins did not differ significantly between conditionally injured versus control neurons over the time points examined, reaching $\sim 50 \%$ at $48 \mathrm{~h}$ after plating (Fig. $4 B$ ). However, we unexpectedly observed a subset of proteins with much higher incorporation rates, delineating an ensemble of axonal proteins robustly synthesized de novo during initial neurite extension (Fig. 5; Extended Data Figure 5-1).

\section{Transcription versus translation in axon outgrowth regulation}

We further examined the contribution of transcription versus translation in driving axonal outgrowth by culturing 


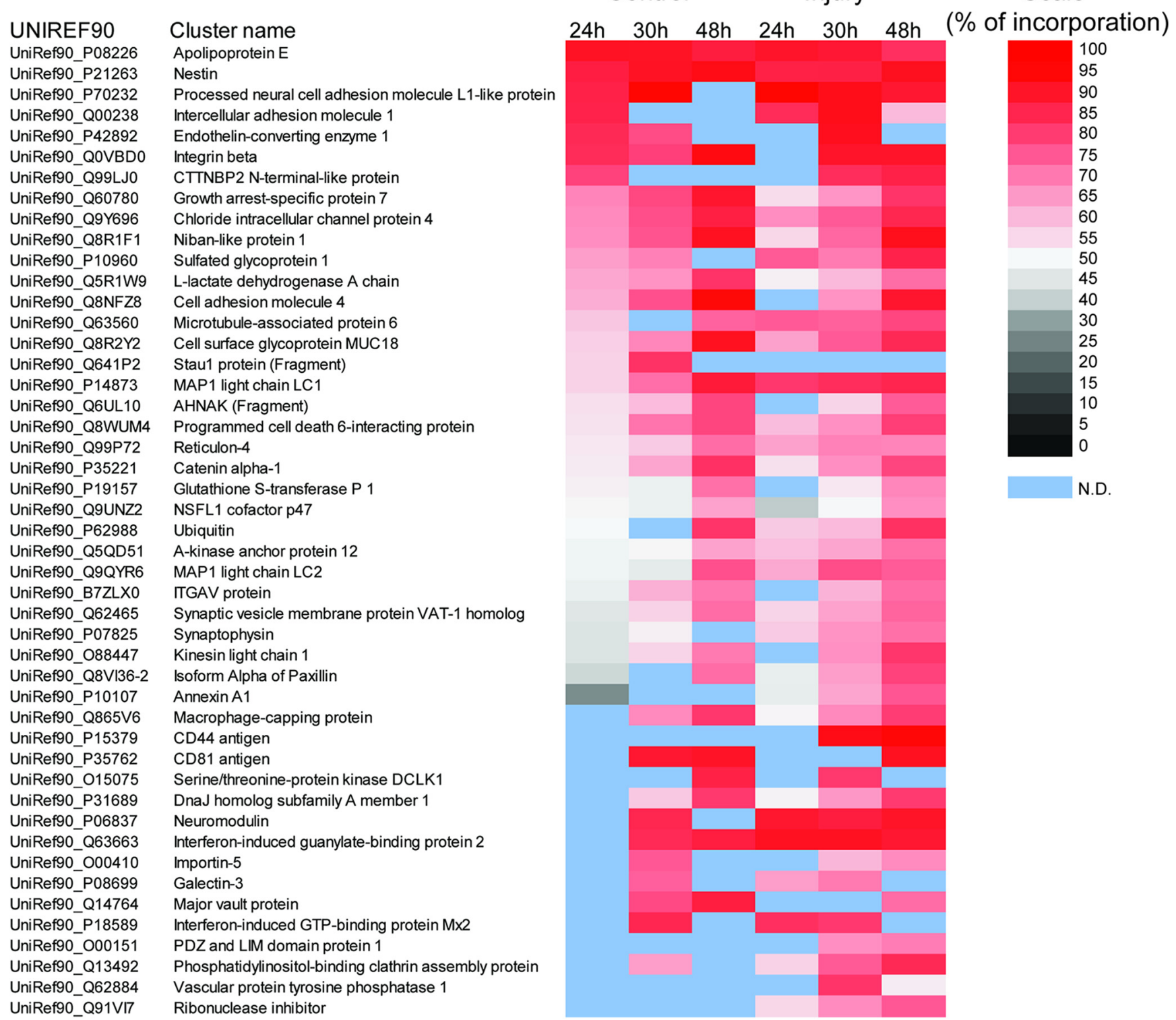

Figure 5. De novo synthesized proteins in sensory neuron outgrowth. Highly synthesized proteins identified in the early time points of rat DRG neuron outgrowth. A similar battery of highly synthesized proteins was found in control and in conditionally injured neurons. Each time point represents a combined sample of 75-100 animal equivalents. See also Extended Data Figure 5-1.

DRG neurons in Boyden chambers in the presence of the transcription inhibitor DRB for the first $12 \mathrm{~h}$ in culture. DRB was then removed and axon outgrowth was quantified at 24,36 , and $48 \mathrm{~h}$, revealing that initial axonal outgrowth can proceed despite reduced transcription (Fig. 6A). This suggests that the robustly translated mRNA subset identified above may be recruited from previously transcribed transcripts that are translated on need. ApoE, a protein best known for its link to Alzheimer's disease (Yu et al., 2014), is one of the most robustly synthesized candidates at the initial stage of axon growth, and one of the ApoE 5'UTR splice variants harbors a CERT-like motif. Interestingly, a previous study described ApoE protein upregulation in SN injury, but did not determine the cell type involved or the role of the upregulated ApoE in the nerve (Melemedjian et al., 2013). Others have reported that exogenous application of ApoE or ApoE modulators can have a beneficial effect on neurite outgrowth (Kosacka et al., 2009). We verified the endogenous synthesis of ApoE in mouse DRG sensory neurons by RiboTag pull-downs from neuronal cultures and quantification of ribosome-associated ApoE RNA splice variants by Nanostring digital expression analysis (Kulkarni, 2011). As shown in Figure 6B, a single $A p o E$ variant is predominant in DRG neurons, and is robustly associated with ribosomes in the pull-downs. Notably, the predominant Tv1 splice variant is not the one that harbors a CERT-like motif (Tv2; Fig. 6B). To assess whether the neuronal synthesis of ApoE might affect neurite outgrowth, we then tested the effects of the ApoE receptor inhibitor lactoferrin on DRG neuron outgrowth in serum-free cultures. Lactoferrin indeed had a modest inhibitory effect on neurite outgrowth, which was more 
A

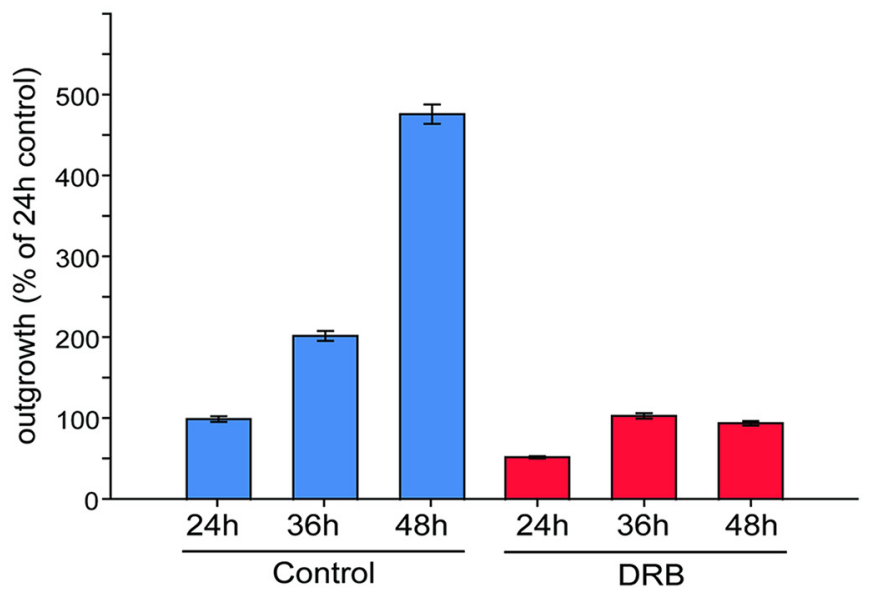

B
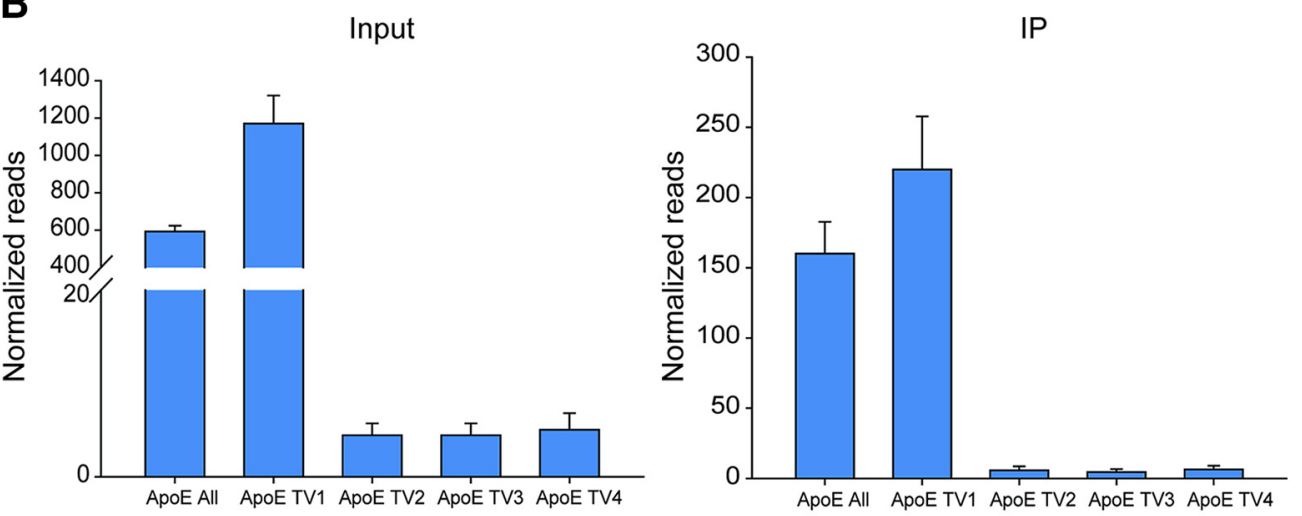

C
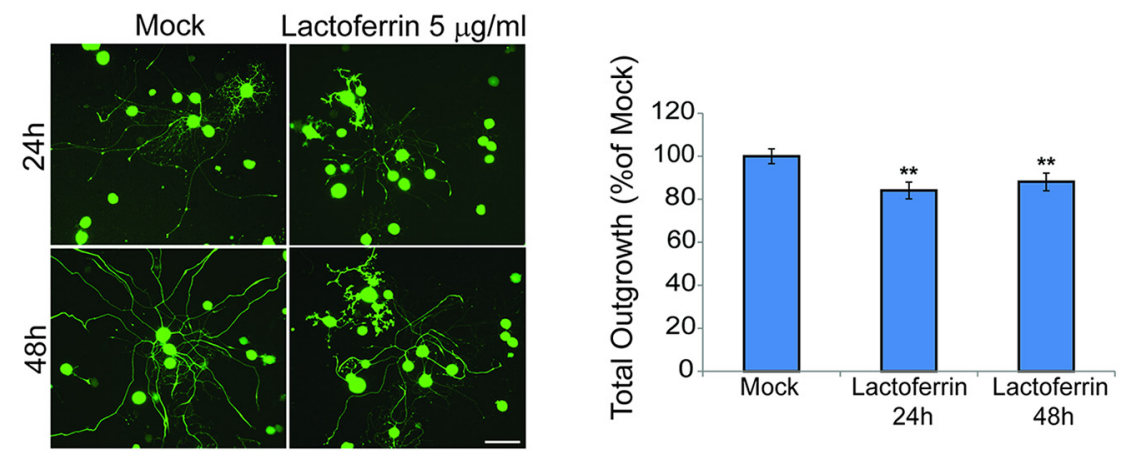

D
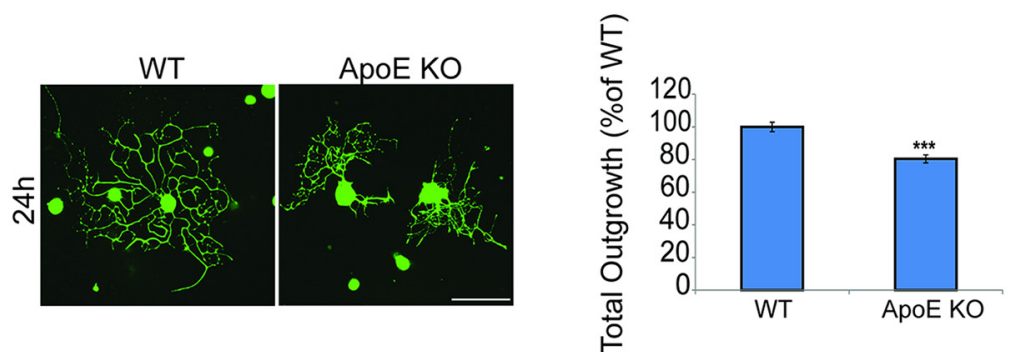

Figure 6. Transcription inhibition and ApoE effects on neurite outgrowth. $\boldsymbol{A}$, Neurite outgrowth comparison for mouse DRG neurons 24, 36, and $48 \mathrm{~h}$ after plating with or without transcription inhibitor (DRB) for first $12 \mathrm{~h}$. All groups were normalized to $24 \mathrm{~h}$ control $(n=3$, Mean \pm SEM). $\boldsymbol{B}$, Expression levels of different ApoE transcript variants (TV) quantified by Nanostring analyses of input and HA-RiboTag pull-downs from wild-type and Adv-Cre-RiboTag DRG. The variants analyzed were ApoE All (GenBank refSeq NM_001305844.1), ApoE TV1 (NM_009696.4), ApoE TV2 (NM_001305819.1), which contains a CERT-like motif, ApoE TV3 (NM_001305843.1), and ApoE TV4 (NM_001305844.1). Data analysis was conducted in nSolver3.0, with normalization to Tubb3 as a reference gene. A large proportion of the most highly expressed ApoE variants are associated with ribosomes, supporting ApoE translation during axonal growth. $\boldsymbol{C}$, YFP-expressing adult mouse DRG neurons were treated with 5- $\mathrm{g} / \mathrm{ml}$ lactoferrin and then 
continued

allowed to grow for $48 \mathrm{~h}$. Representative images at two time points are shown on the left; scale bar: $100 \mu \mathrm{m}$. Quantification of total neurite outgrowth from three independent experiments reveals a significant decrease in axon growth after lactoferrin treatment (right panel). Mean \pm SEM, $n \geq 300$ neurons per experimental group; $* * p<0.01$ (ANOVA with Holm-Sidak method). $\boldsymbol{D}$, DRG neurons from adult wild-type or ApoE KO male mice grown in culture for $24 \mathrm{~h}$ and then fixed and stained for NFH (green). Representative images from ApoE KO and WT neurons are shown on the left; scale bar: $100 \mu \mathrm{m}$. Quantification of total neurite outgrowth from four independent experiments reveals a significant decrease in axon growth in ApoE KO DRG neurons. Mean \pm SEM, $n \geq 250$ neurons per experimental group; $* * * p<0.001$ (Student's $t$ test).

pronounced at the earlier time point (Fig. 6C). Moreover, DRG neurons from ApoE null mice showed a modest yet significant decrease in axon outgrowth in culture (Fig. 6D). These data support the possibility that endogenously synthesized ApoE is secreted by adult sensory neurons for autocrine enhancement of their own axon growth.

We further analyzed concordance of the different datasets in this study by generating a RiboTag dataset from proprioceptive sensory neurons cultured for 24 h, using Runx3-Cre RiboTag cultures. As shown in Figure 7, there is significant overlap in the ribosomeassociated RNA ensemble in culture versus in vivo (Fig. 7A-C; Extended Data Figure 7-1), while there is minimal overlap of both RiboTag datasets with the small SILAC dataset of highly synthesized axonal proteins (Fig. 7C).
A

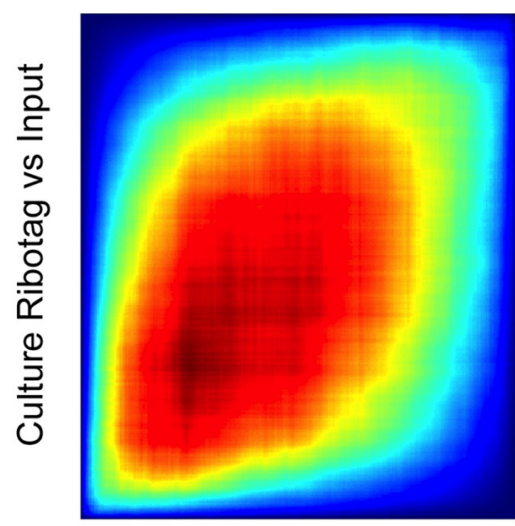

Tissue Ribotag vs Input

\section{B}
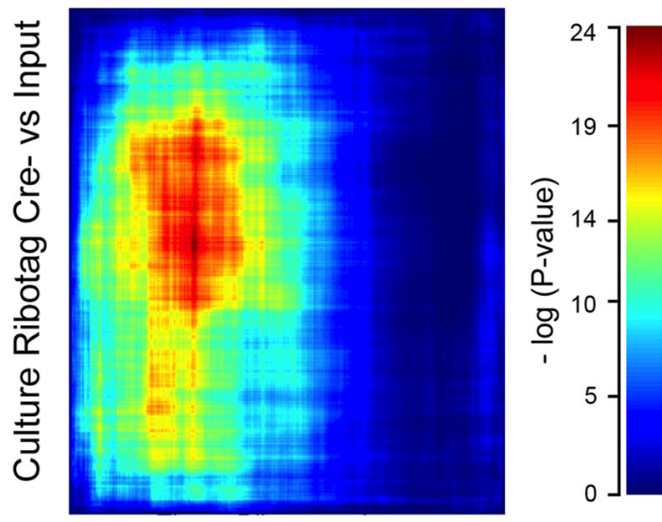

Tissue Ribotag vs Input

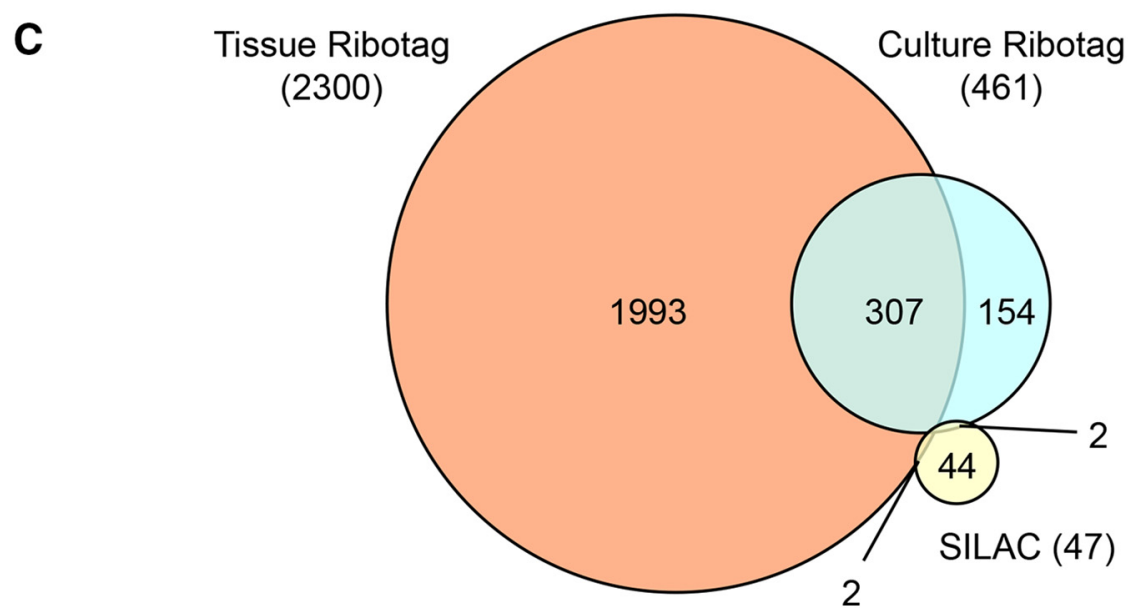

Figure 7. Comparison of datasets. Rank-rank hypergeometric overlap (RRHO) heatmaps comparing RiboTag-enriched genes from ( $\boldsymbol{A})$ cultured DRG neurons and L4-6 DRG tissue (Runx3-Cre driver used for both) and (B) Cre- cultured DRG neurons and Runx3-Cre+ L4-6 DRG tissue. Compared gene lists were sorted by directional $p$ values and plotted as -log10 transformed hypergeometric test $p$ values. Overlap across Runx3-Cre+ samples (cultured neurons and tissue) was significant (A), whereas poorer consistency was observed when correlating Runx3-Cre tissue to Cre- DRG neurons $(\boldsymbol{B})$. $\boldsymbol{C}$, Overlap of genes significantly enriched by Runx3 RiboTag in DRG tissue, Runx3 RiboTag in DRG culture (Extended Data Figure 7-1) and axonal proteins with high translation rates identified by SILAC (Fig. 5). Total number of significantly enriched genes in respective datasets is shown in parentheses. Twofold enrichment in IP versus input and FDR $<0.1$ were set as cutoffs to define RiboTag-enriched genes. 


\section{Discussion}

The above findings reveal multifaceted layers of translational regulation in the neuronal response to injury and subsequent regenerative outgrowth. Translatome-wide analyses in models of neuronal injury or regeneration have mainly focused on compartmentalized translation within injured or regenerating processes (Baleriola and Hengst, 2015; Twiss et al., 2016; Rangaraju et al., 2017; Terenzio et al., 2018). Our RiboTag data reveal widespread translational regulation in the somatic response to injury, most prominently in a subset of upregulated ribosome-associated transcripts containing the CERT motif for Eif4e. This suggests that increased Eif4e activity may fuel the injury response in peripheral neurons, and Eif4e can indeed be rate limiting in mRNA translation (Truitt et al., 2015). Moreover, regulation of Eif4e or its binding proteins has been reported in a number of neuronal trauma or pain models (Chen et al., 2007; Ayuso et al., 2013; Khoutorsky and Price, 2018). Eif4e activity can be regulated by phosphorylation, interaction with different partners or upregulation, offering diverse opportunities to target the pathway (Moy et al., 2017). However, direct targeting of Eif4e for enhancing neuronal regeneration would be a high-risk strategy, since increasing Eif4e levels or activity promotes cellular transformation and cancer cell survival (Truitt et al., 2015; Hu et al., 2016).

In addition to highlighting regulatory aspects of translation in neuronal regeneration, our SILAC analyses identified a subset of transcripts that are robustly translated in the initial stages of axonal outgrowth. Although our SILAC data cannot discriminate between greatly increased synthesis versus very rapid turnover, a recent study that systematically analyzed protein turnover rates in different cell types did not report high turnover in neurons (Mathieson et al., 2018). Early studies suggested that the first phase of axon outgrowth is transcription-independent in sensory neurons (Smith and Skene, 1997), and our findings support that observation, while showing that later stages of outgrowth require new transcription. The data are consistent with initial translation of a cohort of preexisting mRNAs in the early injury response, perhaps ensuring a rapid reaction to lesion before transcriptional changes. The minimal overlap between our axonal SILAC and ganglia or whole-neuron RiboTag datasets might suggest that the SILAC experiment highlighted proteins synthesized within axons. The data may also reflect the inherent technical limitations of using a basic SILAC approach in non-dividing cells, since it was difficult to identify a time point allowing sufficient labeling that also revealed clear differences between conditionally lesioned and naive cultures. Future work in such models should use methods that do not require extensive labeling or pre-incubation periods, such as recently described methods based on O-propargylpuromycin (OPP) labeling (Barrett et al., 2016; Forester et al., 2018), that can also be conducted in tissues and potentially also in vivo (Terenzio et al., 2018).

ApoE is one of the de novo synthesized proteins identified in our analyses. This protein is most prominently studied for its roles in Alzheimer's disease (Yu et al., 2014) but is also implicated in a number of studies of peripheral neuronal injury and regeneration (Kosacka et al., 2009; Li et al., 2010; Melemedjian et al., 2013). Our data suggest that ApoE may have autocrine effects on axon growth, whereby growth-promoting ApoE is synthesized and secreted by the neuron to facilitate its own axon outgrowth. Future studies on this translationally regulated cohort of mRNAs are likely to provide additional new insights on the mechanisms underlying growth and regeneration of injured neurons.

\section{References}

Auer PL, Doerge RW (2010) Statistical design and analysis of RNA sequencing data. Genetics 185:405-416. CrossRef Medline

Ayuso MI, Martínez-Alonso E, Cid C, Alonso de Lecinana M, Alcázar A (2013) The translational repressor elF4E-binding protein 2 (4EBP2) correlates with selective delayed neuronal death after ischemia. J Cereb Blood Flow Metab 33:1173-1181. CrossRef Medline

Bailey TL, Boden M, Buske FA, Frith M, Grant CE, Clementi L, Ren J, Li WW, Noble WS (2009) MEME SUITE: tools for motif discovery and searching. Nucleic Acids Res 37:W202-W208. CrossRef Medline

Baleriola J, Hengst $U$ (2015) Targeting axonal protein synthesis in neuroregeneration and degeneration. Neurotherapeutics 12:5765. CrossRef Medline

Barrett RM, Liu HW, Jin H, Goodman RH, Cohen MS (2016) Cellspecific Profiling of Nascent Proteomes Using Orthogonal Enzymemediated Puromycin Incorporation. ACS Chem Biol. 11:1532-1536. CrossRef Medline

Bauer S, Grossmann S, Vingron M, Robinson PN (2008) Ontologizer 2.0-a multifunctional tool for GO term enrichment analysis and data exploration. Bioinformatics 24:1650-1651. CrossRef Medline

Ben-Yaakov K, Dagan SY, Segal-Ruder Y, Shalem O, Vuppalanchi D, Willis DE, Yudin D, Rishal I, Rother F, Bader M, Blesch A, Pilpel Y, Twiss JL, Fainzilber M (2012) Axonal transcription factors signal retrogradely in lesioned peripheral nerve. EMBO J 31:1350-1363. CrossRef Medline

Brar GA, Weissman JS (2015) Ribosome profiling reveals the what, when, where and how of protein synthesis. Nat Rev Mol Cell Biol 16:651-664. CrossRef Medline

Carlevaro-Fita J, Rahim A, Guigó R, Vardy LA, Johnson R (2016) Cytoplasmic long noncoding RNAs are frequently bound to and degraded at ribosomes in human cells. RNA 22:867-882. CrossRef Medline

Chandran V, Coppola G, Nawabi H, Omura T, Versano R, Huebner EA, Zhang A, Costigan M, Yekkirala A, Barrett L, Blesch A, Michaelevski I, Davis-Turak J, Gao F, Langfelder P, Horvath S, He Z, Benowitz L, Fainzilber M, Tuszynski M, et al. (2016) A systemslevel analysis of the peripheral nerve intrinsic axonal growth program. Neuron 89:956-970. CrossRef Medline

Chen S, Atkins CM, Liu CL, Alonso OF, Dietrich WD, Hu BR (2007) Alterations in mammalian target of rapamycin signaling pathways after traumatic brain injury. J Cereb Blood Flow Metab 27:939949. CrossRef Medline

Cho Y, Sloutsky R, Naegle KM, Cavalli V (2013) Injury-induced HDAC5 nuclear export is essential for axon regeneration. Cell 155:894-908. CrossRef Medline

Cohen LD, Zuchman R, Sorokina O, Müller A, Dieterich DC, Armstrong JD, Ziv T, Ziv NE (2013) Metabolic turnover of synaptic proteins: kinetics, interdependencies and implications for synaptic maintenance. PLoS One 8:e63191CrossRef Medline

da Silva S, Hasegawa H, Scott A, Zhou X, Wagner AK, Han BX, Wang $F$ (2011) Proper formation of whisker barrelettes requires periphery-derived Smad4-dependent TGF-beta signaling. Proc Natl Acad Sci USA 108:3395-3400. CrossRef Medline

Debaisieux S, Encheva V, Chakravarty P, Snijders AP, Schiavo G (2016) Analysis of signaling endosome composition and dynamics using SILAC in embryonic stem cell-derived neurons. Mol Cell Proteomics 15:542-557. CrossRef Medline 
Dobin A, Davis CA, Schlesinger F, Drenkow J, Zaleski C, Jha S, Batut P, Chaisson M, Gingeras TR (2013) STAR: ultrafast universal RNAseq aligner. Bioinformatics 29:15-21. CrossRef Medline

Dulin JN, Antunes-Martins A, Chandran V, Costigan M, Lerch JK, Willis DE, Tuszynski MH (2015) Transcriptomic approaches to neural repair. J Neurosci 35:13860-13867. CrossRef Medline

Feng G, Mellor RH, Bernstein M, Keller-Peck C, Nguyen QT, Wallace M, Nerbonne JM, Lichtman JW, Sanes JR (2000) Imaging neuronal subsets in transgenic mice expressing multiple spectral variants of GFP. Neuron 28:41-51. Medline

Forester CM, Zhao Q, Phillips NJ, Urisman A, Chalkley RJ, OsesPrieto JA, Zhang L, Ruggero D, Burlingame AL (2018) Revealing nascent proteomics in signaling pathways and cell differentiation. Proc Natl Acad Sci USA 115:2353-2358. CrossRef Medline

Grant CE, Bailey TL, Noble WS (2011) FIMO: Scanning for occurrences of a given motif. Bioinformatics 27:1017-1018. CrossRef Medline

Hanz S, Perlson E, Willis D, Zheng JQ, Massarwa R, Huerta JJ, Koltzenburg M, Kohler M, van-Minnen J, Twiss JL, Fainzilber M (2003) Axoplasmic importins enable retrograde injury signaling in lesioned nerve. Neuron 40:1095-1104. Medline

Heiman M, Schaefer A, Gong S, Peterson JD, Day M, Ramsey KE, Suárez-Fariñas M, Schwarz C, Stephan DA, Surmeier DJ, Greengard P, Heintz N (2008) A translational profiling approach for the molecular characterization of CNS cell types. Cell 135:738-748. CrossRef Medline

Hoedt E, Zhang G, Neubert TA (2014) Stable isotope labeling by amino acids in cell culture (SILAC) for quantitative proteomics. Adv Exp Med Biol 806:93-106. CrossRef Medline

Hu K, Dai HB, Qiu ZL (2016) mTOR signaling in osteosarcoma: oncogenesis and therapeutic aspects (review). Oncol Rep 36:12191225. CrossRef Medline

Ingolia NT, Lareau LF, Weissman JS (2011) Ribosome profiling of mouse embryonic stem cells reveals the complexity and dynamics of mammalian proteomes. Cell 147:789-802. CrossRef Medline

Jaegle M, Ghazvini M, Mandemakers W, Piirsoo M, Driegen S, Levavasseur F, Raghoenath S, Grosveld F, Meijer D (2003) The POU proteins Brn-2 and Oct- 6 share important functions in Schwann cell development. Genes Dev 17:1380-1391. CrossRef Medline

Jiménez CR, Stam FJ, Li KW, Gouwenberg Y, Hornshaw MP, De Winter F, Verhaagen J, Smit AB (2005) Proteomics of the injured rat sciatic nerve reveals protein expression dynamics during regeneration. Mol Cell Proteomics 4:120-132. CrossRef Medline

Jung H, Yoon BC, Holt CE (2012) Axonal mRNA localization and local protein synthesis in nervous system assembly, maintenance and repair. Nat Rev Neurosci 13:308-324. CrossRef Medline

Khoutorsky A, Price TJ (2018) Translational control mechanisms in persistent pain. Trends Neurosci 41:100-114. CrossRef Medline

Kosacka J, Gericke M, Nowicki M, Kacza J, Borlak J, SpanelBorowski K (2009) Apolipoproteins D and E3 exert neurotrophic and synaptogenic effects in dorsal root ganglion cell cultures. Neuroscience 162:282-291. CrossRef Medline

Kulkarni MM (2011) Digital multiplexed gene expression analysis using the NanoString nCounter system. Curr Protoc Mol Biol Chapter 25:Unit25B 10. CrossRef Medline

Lallemand Y, Luria V, Haffner-Krausz R, Lonai P (1998) Maternally expressed PGK-Cre transgene as a tool for early and uniform activation of the Cre site-specific recombinase. Transgenic Res 7:105112. Medline

Levanon D, Bernstein Y, Negreanu V, Bone KR, Pozner A, Eilam R, Lotem J, Brenner O, Groner Y (2011) Absence of Runx3 expression in normal gastrointestinal epithelium calls into question its tumour suppressor function. EMBO Mol Med 3:593-604. CrossRef Medline

Li FQ, Fowler KA, Neil JE, Colton CA, Vitek MP (2010) An apolipoprotein E-mimetic stimulates axonal regeneration and remyelination after peripheral nerve injury. J Pharmacol Exp Ther 334:106115. CrossRef Medline

Mathieson T, Franken H, Kosinski J, Kurzawa N, Zinn N, Sweetman G, Poeckel D, Ratnu VS, Schramm M, Becher I, Steidel M, Noh
KM, Bergamini G, Beck M, Bantscheff M, Savitski MM (2018) Systematic analysis of protein turnover in primary cells. Nat Commun 9:689. CrossRef Medline

Melemedjian OK, Yassine HN, Shy A, Price TJ (2013) Proteomic and functional annotation analysis of injured peripheral nerves reveals ApoE as a protein upregulated by injury that is modulated by metformin treatment. Mol Pain 9:14. CrossRef Medline

Michaelevski I, Medzihradszky KF, Lynn A, Burlingame AL, Fainzilber M (2010a) Axonal transport proteomics reveals mobilization of translation machinery to the lesion site in injured sciatic nerve. Mol Cell Proteomics 9:976-987. CrossRef

Michaelevski I, Segal-Ruder Y, Rozenbaum M, Medzihradszky KF, Shalem O, Coppola G, Horn-Saban S, Ben-Yaakov K, Dagan SY, Rishal I, Geschwind DH, Pilpel Y, Burlingame AL, Fainzilber M (2010b) Signaling to transcription networks in the neuronal retrograde injury response. Sci Signal 3:ra53. CrossRef

Moy JK, Khoutorsky A, Asiedu MN, Black BJ, Kuhn JL, BarragánIglesias $\mathrm{P}$, Megat S, Burton MD, Burgos-Vega CC, Melemedjian OK, Boitano S, Vagner J, Gkogkas CG, Pancrazio JJ, Mogil JS, Dussor G, Sonenberg N, Price TJ (2017) The MNK-elF4E signaling axis contributes to injury-induced nociceptive plasticity and the development of chronic pain. J Neurosci 37:7481-7499. CrossRef Medline

Ong SE, Blagoev B, Kratchmarova I, Kristensen DB, Steen H, Pandey A, Mann M (2002) Stable isotope labeling by amino acids in cell culture, SILAC, as a simple and accurate approach to expression proteomics. Mol Cell Proteomics 1:376-386. Medline

Perry RB, Doron-Mandel E, lavnilovitch E, Rishal I, Dagan SY, Tsoory M, Coppola G, McDonald MK, Gomes C, Geschwind DH, Twiss JL, Yaron A, Fainzilber M (2012) Subcellular knockout of importin $\beta 1$ perturbs axonal retrograde signaling. Neuron 75:294-305. CrossRef Medline

Perry RB, Rishal I, Doron-Mandel E, Kalinski AL, Medzihradszky KF, Terenzio M, Alber S, Koley S, Lin A, Rozenbaum M, Yudin D, Sahoo PK, Gomes C, Shinder V, Geraisy W, Huebner EA, Woolf CJ, Yaron A, Burlingame AL, Twiss JL, et al. (2016) Nucleolinmediated RNA localization regulates neuron growth and cycling cell size. Cell Rep 16:1664-1676. CrossRef Medline

Piedrahita JA, Zhang SH, Hagaman JR, Oliver PM, Maeda N (1992) Generation of mice carrying a mutant apolipoprotein $\mathrm{E}$ gene inactivated by gene targeting in embryonic stem cells. Proc Natl Acad Sci USA 89:4471-4475. Medline

Rangaraju V, Tom Dieck S, Schuman EM (2017) Local translation in neuronal compartments: how local is local? EMBO Rep 18:693711. CrossRef Medline

Rishal I, Fainzilber M (2014) Axon-soma communication in neuronal injury. Nat Rev Neurosci 15:32-42. CrossRef Medline

Rishal I, Golani O, Rajman M, Costa B, Ben-Yaakov K, Schoenmann Z, Yaron A, Basri R, Fainzilber M, Galun M (2013) WIS-NeuroMath enables versatile high throughput analyses of neuronal processes. Dev Neurobiol 73:247-256. CrossRef Medline

Robinson MD, McCarthy DJ, Smyth GK (2010) edgeR: a Bioconductor package for differential expression analysis of digital gene expression data. Bioinformatics 26:139-140. CrossRef Medline

Sanz E, Yang L, Su T, Morris DR, McKnight GS, Amieux PS (2009) Cell-type-specific isolation of ribosome-associated mRNA from complex tissues. Proc Natl Acad Sci USA 106:13939-13944. CrossRef Medline

Shigeoka T, Jung H, Jung J, Turner-Bridger B, Ohk J, Lin JQ, Amieux PS, Holt CE (2016) Dynamic axonal translation in developing and mature visual circuits. Cell 166:181-192. CrossRef Medline

Shin JE, Cho Y, Beirowski B, Milbrandt J, Cavalli V, DiAntonio A (2012) Dual leucine zipper kinase is required for retrograde injury signaling and axonal regeneration. Neuron 74:1015-1022. CrossRef Medline

Slomnicki LP, Pietrzak M, Vashishta A, Jones J, Lynch N, Elliot S, Poulos E, Malicote D, Morris BE, Hallgren J, Hetman M (2016) Requirement of neuronal ribosome synthesis for growth and maintenance of the dendritic tree. J Biol Chem 291:5721-5739. CrossRef 
Smith DS, Skene JH (1997) A transcription-dependent switch controls competence of adult neurons for distinct modes of axon growth. J Neurosci 17:646-658. Medline

Spellman DS, Deinhardt K, Darie CC, Chao MV, Neubert TA (2008) Stable isotopic labeling by amino acids in cultured primary neurons: application to brain-derived neurotrophic factor-dependent phosphotyrosine-associated signaling. Mol Cell Proteomics 7:10671076. CrossRef Medline

Sun S, Sun Y, Ling SC, Ferraiuolo L, McAlonis-Downes M, Zou Y, Drenner K, Wang Y, Ditsworth D, Tokunaga S, Kopelevich A, Kaspar BK, Lagier-Tourenne C, Cleveland DW (2015) Translational profiling identifies a cascade of damage initiated in motor neurons and spreading to glia in mutant SOD1-mediated ALS. Proc Natl Acad Sci USA 112:E6993-E7002. CrossRef Medline

Tao J, Wu H, Coronado AA, de Laittre E, Osterweil EK, Zhang Y, Bear MF (2016) Negative allosteric modulation of mGluR5 partially corrects pathophysiology in a mouse model of Rett syndrome. J Neurosci 36:11946-11958. CrossRef

Tasdemir-Yilmaz OE, Segal RA (2016) There and back again: coordinated transcription, translation and transport in axonal survival and regeneration. Curr Opin Neurobiol 39:62-68. CrossRef Medline

Terenzio M, Schiavo G, Fainzilber M (2017) Compartmentalized signaling in neurons: from cell biology to neuroscience. Neuron 96: 667-679. CrossRef Medline

Terenzio M, Koley S, Samra N, Rishal I, Zhao Q, Sahoo PK, Urisman A, Marvaldi L, Oses-Prieto JA, Forester C, Gomes C, Kalinski AL, Di Pizio A, Doron-Mandel E, Perry RB, Koppel I, Twiss JL, Burlingame AL, Fainzilber M (2018) Locally translated mTOR controls axonal local translation in nerve injury. Science 359:1416-1421. CrossRef Medline

Truitt ML, Conn CS, Shi Z, Pang X, Tokuyasu T, Coady AM, Seo Y, Barna M, Ruggero D (2015) Differential requirements for elF4E dose in normal development and cancer. Cell 162:59-71. CrossRef Medline

Twiss JL, Smith DS, Chang B, Shooter EM (2000) Translational control of ribosomal protein L4 mRNA is required for rapid neurite regeneration. Neurobiol Dis 7:416-428. CrossRef Medline
Twiss JL, Kalinski AL, Sachdeva R, Houle JD (2016) Intra-axonal protein synthesis - a new target for neural repair? Neural Regen Res 11:1365-1367. CrossRef Medline

Ultanir SK, Yadav S, Hertz NT, Oses-Prieto JA, Claxton S, Burlingame AL, Shokat KM, Jan LY, Jan YN (2014) MST3 kinase phosphorylates TAO1/2 to enable myosin Va function in promoting spine synapse development. Neuron 84:968-982. CrossRef Medline

Verma P, Chierzi S, Codd AM, Campbell DS, Meyer RL, Holt CE, Fawcett JW (2005) Axonal protein synthesis and degradation are necessary for efficient growth cone regeneration. J Neurosci 25: 331-342. CrossRef Medline

Williams KR, McAninch DS, Stefanovic S, Xing L, Allen M, Li W, Feng Y, Mihailescu MR, Bassell GJ (2016) hnRNP-Q1 represses nascent axon growth in cortical neurons by inhibiting Gap-43 mRNA translation. Mol Biol Cell 27:518-534. CrossRef Medline

Willis DE, Twiss JL (2011) Profiling axonal mRNA transport. Methods Mol Biol 714:335-352. CrossRef Medline

Yang L, Cai CL, Lin L, Qyang Y, Chung C, Monteiro RM, Mummery CL, Fishman Gl, Cogen A, Evans S (2006) Isl1Cre reveals a common Bmp pathway in heart and limb development. Development 133:1575-1585. CrossRef Medline

Yu JT, Tan L, Hardy J (2014) Apolipoprotein E in Alzheimer's disease: an update. Annu Rev Neurosci 37:79-100. CrossRef Medline

Zhang G, Deinhardt K, Neubert TA (2014) Stable isotope labeling by amino acids in cultured primary neurons. Methods Mol Biol 1188: 57-64. CrossRef Medline

Zhang KX, Tan L, Pellegrini M, Zipursky SL, McEwen JM (2016) Rapid changes in the translatome during the conversion of growth cones to synaptic terminals. Cell Rep 14:1258-1271. CrossRef Medline

Zheng JQ, Kelly TK, Chang B, Ryazantsev S, Rajasekaran AK, Martin $K C$, Twiss $J L$ (2001) A functional role for intra-axonal protein synthesis during axonal regeneration from adult sensory neurons. J Neurosci 21:9291-9303. Medline

Zhou W, Zhang Y, Li Y, Wei Y-S, Liu G, Liu D-P, Pleasure SJ, Xie W, Zhao C (2010) A transgenic Cre mouse line for the study of cortical and hippocampal development. Genesis 48:343-350. CrossRef 